\title{
Identification of molecular markers for the Pc39 gene conferring resistance to crown rust in oat
}

\author{
Sylwia Sowa ${ }^{1}\left[\right.$ : Edyta Paczos-Grzęda ${ }^{1}$ (i)
}

Received: 22 July 2019 / Accepted: 3 January 2020 / Published online: 11 January 2020

(c) The Author(s) 2020

\begin{abstract}
Key message Six new PCR-based markers for the Pc39 crown rust resistance gene in Avena sativa L. were developed. Pc39 was mapped to Mrg11 of the oat consensus map using BLASTn analysis.

Abstract The aim of this study was the identification of molecular markers for the Pc39 gene in cultivated oat (Avena sativa L.). $P c 39$ is a major race-specific crown rust resistance gene originally found in an Israeli accession of the wild hexaploid Avena sterilis. The effectiveness of this gene in Europe has decreased in recent years, but is still relatively high and breeding programs would benefit from the availability of molecular markers to aid in its mapping and deployment. The complexity of the oat genome poses a significant obstacle to genetic research. No oat rust resistance genes have yet been cloned, and even the number of relevant molecular markers is very limited. Here, genotyping of a segregating population derived from a cross 'Celer' (Pc39)/STH9210 (susceptible) was conducted using RAPD- and SRAP-PCR-based methods, as well as microarraybased DArT ${ }^{\mathrm{TM}}$ and next-generation sequencing DArTseq ${ }^{\mathrm{TM}}$ techniques. Markers associated with $P c 39$ were placed on the hexaploid oat consensus linkage group Mrg 11 at 3.7-6.7 cM. Six new PCR-based markers were developed to allow identification of the resistant $P c 39$ allele. These tightly linked markers will be useful in marker-assisted selection, with the closest, SCAR_3456624, being within $0.37 \mathrm{cM}$ of $P c 39$. The newly developed markers could find applications in the fine mapping or positional cloning of this gene. Moreover, easy-to-use PCR-based markers linked to Pc39 could facilitate the utilization of this gene in oat breeding programs, especially as a component of crown rust resistance gene pyramids.
\end{abstract}

\section{Introduction}

Fungal diseases are an important constraint to cereal production. In oats (Avena spp.), crown rust caused by Puccinia coronata Cda. f. sp. avenae P. Syd. \& Syd. (Pca) is considered the most destructive fungal disease, causing great yield and grain quality loses (Simons 1985). The chief method of control for crown rust is resistance conditioned by major resistance (R) genes (Cabral et al. 2014). Large-scale cultivation of varieties containing a single $\mathrm{R}$ gene increases the probability of emergence of new pathogen races able

Communicated by Albrecht E. Melchinger.

Electronic supplementary material The online version of this article (https://doi.org/10.1007/s00122-020-03533-z) contains supplementary material, which is available to authorized users.

Edyta Paczos-Grzęda

edyta.paczos@up.lublin.pl

1 Institute of Plant Genetics, Breeding and Biotechnology, University of Life Sciences in Lublin, Lublin, Poland to overcome this gene. Thus, pyramiding genes with different race specificities may extend their use. Successful gene pyramiding depends upon several factors including efficient identification of component genes (Joshi and Nayak 2010; Kordrostami and Rahimi 2015). So far, selection of rust-resistant oat plants has been based on phenotypic observation using pathogen isolates with defined infection profiles. However, finding the appropriate isolate to detect individual genes is difficult and time-consuming and, in the case of pyramid structures composed of genes with epistatic effects, almost impossible (Kebede et al. 2019). Genotyping and use of markers linked to the genes of interest are a promising alternative to these laborious physiological tests (Tomczyńska and Śliwka 2011; Kordrostami and Rahimi 2015). There are many examples of effective use of markerassisted pyramiding, such as the introduction of the Xa21, $x a 5, x a 4$ and $x a 13$ genes increasing resistance to bacterial blast in rice (Huang et al. 1997; Hittalmani et al. 2000), as well as the $L r 41, L r 42, L r 43$ genes providing resistance to brown rust in wheat (Cox et al. 1993). This method has also proved to be successful in the pyramiding of the 
$P m 2+P m 4 a, P m 2+P m 21, P m 4 a+P m 21$ wheat powdery mildew resistance (Liu et al. 2000) or Rsv1, Rsv3, Rsv4 resistance to the barley yellow mosaic virus (Werner et al. 2005).

In the Avena genus, close to $100 P$. coronata resistance (Pc) genes have been identified (CDL 2018), and much work has been dedicated to chromosome localization and characterization of allelic relationships of these genes (Penner et al. 1993; Rooney et al. 1994; Wilson and McMullen 1997; Bush and Wise 1998; Wight et al. 2004; Kulcheski et al. 2010; McCartney et al. 2011; Gnanesh et al. 2013; Kebede et al. 2019). However, the complexity and size (12.5 GB) of the oat genome present significant obstacles to genetic research, with redundancy being generated by polyploidy as well as the high repetitive DNA content (Jellen et al. 1994; Jellen et al. 1997; Gutierrez-Gonzalez and Garvin 2011; Yan et al. 2016). Cultivated oat (Avena sativa L.) is an allohexaploid with basic chromosome number of $x=7$ and the genome constitution of AACCDD (Rajhathy and Thomas 1974). Due to a high degree of similarity between the A and D genomes, nonhomologous pairing is possible, so the hexaploid oat chromosomes contain substantial rearrangements relative to the basic diploid ancestral chromosomes (Chen and Armstrong 1994; Leggett and Markhand 1995). The presence of numerous multigene families adds a further difficulty to developing linkage maps and assigning map positions to markers (Wight et al. 2003; Gutierrez-Gonzalez and Garvin 2011; Chaffin et al. 2016).

Our previous research has been focused on monitoring of the occurrence and harmfulness of $P$. coronata populations, as well as evaluating the effectiveness and potential of resistance in breeding materials. Results indicate that many $P c$ genes can be still effective against crown rust races occurring in central Europe (Paczos-Grzęda and Sowa 2019); however, the number of molecular markers for those genes useful in breeding is very limited.

Pc39 is a major race-specific crown rust resistance gene incorporated into common oat from the wild hexaploid oat Avena sterilis F-366 collected in Israel and identified by Fleischmann and McKenzie (1968). Šebesta (1983) analyzing virulence of crown rust samples isolated from 1977 to 1980 from various European countries found $P c 39$ to be one of the most effective genes at that time. Similar surveys were conducted by Šebesta et al. (1997) from 1990 to 1994, and by Šebesta et al. (2003) from 1995 to 2001, when Pc39 was also described as highly effective, although $P c 39$ virulent isolates were first found. A few years later (2006-2008), Jiráková and Hanzalová (2008) detected no isolates breaking down $P c 39$ determined resistance in a set of isolates derived from the Czech crown rust population. The highest frequencies of virulence to Pc39 in Europe were detected in isolates collected from 2013 to 2015 in Poland, when they ranged from 16 to $31 \%$ depending on the year (Paczos-Grzęda and
Sowa 2019). Compared to European countries, in the USA, virulence toward $P c 39$ analyzed from 2001 to 2005 was very high, especially in $P$. coronata isolates derived from spring rather than winter cultivars (Carson 2011). Similarly, virulence frequencies to Pc39 isolates from Canada from 2007 to 2009 were over $88 \%$ (Chong et al. 2011), even reaching 100\% from 2010 to 2015 (Menzies et al. 2019). This means that $P c 39$ is still relatively effective in Europe, but wide use of this gene in North American breeding has contributed to the spread of virulence against $P c 39$ in $P$. coronata populations in this region.

The only Polish cultivar carrying Pc39 is 'Celer.' This cultivar was selected on the basis of crown rust resistance measurements in a set of new and historical oat cultivars representing 120 years of Polish oat breeding (Sowa and Paczos-Grzęda in press). 'Celer' presented the highest level of resistance in seedling and adult plant stages. The infection profile of this cultivar matched the pattern of the reference line for the $P c 39$ crown rust resistance gene. Additionally, 'Celer' was crossed with the $P c 39$ reference line and allelism tests confirmed that the resistance of both is conditioned by the same locus. The cultivar 'Celer' is well adapted to central Europe climatic conditions, high yielding and characterized by a number of favorable agronomic traits; therefore, it can be successfully used as a direct $P c 39$ gene donor.

The objective of this study was the identification of molecular markers linked to the $P c 39$ gene using a $\mathrm{F}_{2}$ population derived from a cross 'Celer'/STH9210, and development of simple, PCR-based markers for this gene, supporting effective $P c 39$ gene introduction in breeding programs. Markers closely linked to the gene also facilitated location of the Pc39 gene on the oat consensus map.

\section{Materials and methods}

\section{Plant materials}

Pc39 mapping was conducted in $\mathrm{F}_{2}$ and $\mathrm{F}_{2: 3}$ populations derived from a cross 'Celer'/STH9210 developed at the Institute of Plant Genetics, Breeding and Biotechnology, University of Life Sciences in Lublin, Poland. 'Celer' is a spring oat variety produced in the Plant Breeding Station in Borów, Poland with the pedigree Góral//Flämingsnova// Tiger/Pc39//Pan. STH9210 is an oat breeding line developed by the Plant Breeding Company in Strzelce and is susceptible to crown rust infection. PCR markers generated in this project were validated on a set of 22 oat cultivars (Table 4), seven of which are Polish-susceptible oat varieties (Sowa and Paczos-Grzęda in press), and the remaining 15 developed in either AAFC Winnipeg, Manitoba, Canada or North Dakota State University, Fargo, USA, having Pc39 in their pedigrees. 


\section{Crown rust inoculation}

Two hundred twenty seeds of $\mathrm{F}_{2}$ 'Celer'/STH9210 progeny were grown in plug trays filled with a universal substrate containing peat. Two hundred two progeny plants were phenotyped based on the host-pathogen test (Hsam et al. 1997) conducted on the first leaves of 10-day-old seedlings as described in Sowa et al. (2016). Crown rust resistance was tested using three $P$. coronata isolates $13.3 / 1 ; 94.1 / 4$ and 107.2/3 (Table 1). The pathotypes were selected from a wide collection of single-pustule isolates derived from populations collected in Poland between the years 2010 and 2014 according to the method described by Sowa et al. (2016). One leaf from each seedling was cut into three 3 -cm-long fragments, and fragments were divided across separate 12 -well culture plates with agar $(0.6 \%)$ containing benzimidazole $(3.4 \mathrm{mM})$. A single-leaf fragment of the susceptible cultivar 'Kasztan' was used as infection control for each well. Inoculations were performed in a settling tower to provide 500-700 spores of $P$. coronata per $1 \mathrm{~cm}^{2}$. Plates were incubated for 10 days in a phytotron at $18{ }^{\circ} \mathrm{C}$ with $70 \%$ humidity and light intensity of approximately $4 \mathrm{kLx}$ for a 16-h photoperiod.

After seedling tests, all individuals were planted in the experimental farm of the University of Life Sciences in Lublin (Czesławice $\left.51^{\circ} 18^{\prime} \mathrm{N}, 22^{\circ} 15^{\prime} \mathrm{E}\right) . \mathrm{F}_{2: 3}$ generation seeds were collected from $155 \mathrm{~F}_{2}$ individuals. Sixteen plants from each $\mathrm{F}_{3}$ line were tested with $P$. coronata isolates $13.3 / 1$ and 94.1/4 using the host-pathogen methodology cited above.

\section{Disease rating}

Assessment of crown rust disease symptoms was performed after 12 days using 0-4 infection-type (IT) qualitative scale, which was transformed to S, MS, MR, R and HR, where $\mathrm{S}=4=$ susceptible (large-to-moderately large pustules with little or no chlorosis); $\mathrm{MS}=3=$ moderately susceptible (moderately large pustules surrounded by extensive chlorosis); $\mathrm{MR}=2,2 \mathrm{~N}, 12 \mathrm{C}, ; 1 \mathrm{C}=$ moderately resistant (small pustule surrounded by chlorosis or necrosis); $\mathrm{R}=;-\mathrm{N}$, ;C, ;+ C, $1 \mathrm{~N}=$ resistant (chlorotic or necrotic flecking); and $0=\mathrm{HR}=$ highly resistant (no visible reaction) (Murphy 1935; Carson 2009; Sowa et al. 2016) (see Nazareno et al. 2018 for an illustration). Reactions to the crown rust isolate infections were grouped into two classes: Phenotypes described as S and MS were considered as susceptible, and the remainder as resistant.

\section{DNA extraction}

For molecular analysis, genomic DNA was extracted from the frozen tissue of fresh 10-day-old leaf material of all $\mathrm{F}_{2}$ individuals using DNeasy Plant Mini Kit (Qiagen). DNA integrity and quality were evaluated by electrophoresis on $1.5 \%$ agarose gel. The DNA concentration was determined with NanoDrop2000 spectrophotometry and normalized to $100 \mathrm{ng} / \mu \mathrm{l}$.

\section{Bulks preparation}

To identify markers linked to Pc39, RAPD and SRAP analyses were carried out by BSA (Bulk Segregant Analysis) (Michelmore et al. 1991). Bulks were made by combining equal amounts of DNA from 15 individual homozygous resistant and 15 homozygous susceptible $\mathrm{F}_{2}$ plants. Homozygosity was determined by inoculation of $\mathrm{F}_{3}$ families with crown rust isolates 13.3/1 and 94.1/4 as above.

Screening of RAPD and SRAP primers was performed by comparing the amplification products from bulks of DNAs from resistant and susceptible plants as well as DNAs from population parental forms and DNA from line Pc39, the initial source of the Pc39 crown rust resistance gene.

\section{RAPD analysis}

PCR reactions were performed according to the RAPD method described by Williams et al. (1990) with modifications. The 520 primers used correspond to Operon Technologies kits A-Z (https://www.eurofinsgenomics.eu). Amplifications were carried out in final volumes of $10 \mu \mathrm{L}$ containing $20 \mathrm{ng}$ of template DNA, $1 \times$ DreamTaq $^{\mathrm{TM}}$ Buffer $(750 \mathrm{mM}$ Tris- $\mathrm{HCl}\left(\mathrm{pH} 8.8\right.$ at $\left.25^{\circ} \mathrm{C}\right), 200 \mathrm{mM}\left(\mathrm{NH}_{4}\right)_{2} \mathrm{SO}_{4}, 0.1 \%$ (v/v) Tween 20) with $2 \mathrm{mM} \mathrm{MgCl}_{2}, 0.5 \mathrm{U}^{\text {DreamTaq }}{ }^{\mathrm{TM}}$ DNA polymerase (Thermo Fisher Scientific), $0.16 \mathrm{mM}$ of each dNTP and $0.8 \mu \mathrm{M}$ oligonucleotide primer. The PCR was completed using the Biometra T1 Professional Basic thermocycler programmed for $3 \mathrm{~min}$ in $95{ }^{\circ} \mathrm{C}$ of initial denaturation, 45
Table 1 Virulence spectrum of $P$. coronata $\mathrm{f}$. sp. avenae pathotypes used for testing resistance of the $\mathrm{F}_{2} / \mathrm{F}_{2: 3}$ populations derived from 'Celer'/STH9210

\begin{tabular}{lll}
\hline No. & $\begin{array}{l}\text { Puccinia coronata } \\
\text { isolate }\end{array}$ & Virulence to crown rust differentials \\
\hline 1. & $13.3 / 1$ & Pc36, Pc38, Pc40, Pc46, Pc55, Pc56, Pc96, Pc97, Pc98, Pc103-1 \\
2. & $94.1 / 4$ & Pc14, Pc36, Pc40, Pc45, Pc46, Pc51, Pc54, Pc55, Pc57, Pc64, \\
& & Pc67, Pc70, Pc96, Pc97, Pc98, Pc101, Pc103-1, Pc104 \\
3. & $107.2 / 3$ & Pc35, Pc38, Pc56, Pc58, Pc67, Pc96, Pc97, Pc103-1 \\
\hline
\end{tabular}


cycles: $94{ }^{\circ} \mathrm{C}-45 \mathrm{~s}, 37{ }^{\circ} \mathrm{C}-45 \mathrm{~s}, 72{ }^{\circ} \mathrm{C}-1 \mathrm{~min}$, with a final extension at $72{ }^{\circ} \mathrm{C}$ for $7 \mathrm{~min}$.

\section{SRAP analysis}

For the SRAP assay, the PCR mix of $10 \mu \mathrm{L}$ final volume contained $25 \mathrm{ng}$ of template DNA, $1 \times$ DreamTaq $^{\mathrm{TM}}$ Buffer, $2 \mathrm{mM} \mathrm{MgCl}$, $0.6 \mathrm{U}_{\text {DreamTaq }}{ }^{\mathrm{TM}}$ DNA polymerase (Thermo Fisher Scientific), $0.2 \mathrm{mM}$ of each dNTP and $0.4 \mu \mathrm{M}$ of forward and reverse primers. The amplification protocol was as follows: $94{ }^{\circ} \mathrm{C}$ for $3 \mathrm{~min}$ (pre-denaturation); five cycles of $94{ }^{\circ} \mathrm{C}$ for $1 \mathrm{~min}, 35^{\circ} \mathrm{C}$ for $1 \mathrm{~min}$, and $72{ }^{\circ} \mathrm{C}$ for $1 \mathrm{~min}$; 36 cycles of $94{ }^{\circ} \mathrm{C}$ for $1 \mathrm{~min}, 50^{\circ} \mathrm{C}$ for $1 \mathrm{~min}$, and $72{ }^{\circ} \mathrm{C}$ for $1 \mathrm{~min}$; and a final extension of $72^{\circ} \mathrm{C}$ for $7 \mathrm{~min}(\mathrm{Li}$ and Quiros 2001). Thirty-two forward and 32 reverse SRAP primers were used in 1032 primer combinations. The core forward (5'-TGAGTCCAAACCGG-3') and reverse (5'-GAC ACCGTACGAATT- $3^{\prime}$ ) primer sequence was followed by three selective, but random nucleotides (Li and Quiros 2001; Budak et al. 2004).

\section{PCR products separation}

Products of amplification were separated on $1.5 \%$ agarose gel containing $5 \mu \mathrm{g} / \mathrm{ml} \mathrm{EtBr}$ in 1xTBE Buffer $(90 \mathrm{mM}$ Tris-borate, 2 mM EDTA, pH 8.0). To establish molecular weight of the products, Gene Ruler ${ }^{\mathrm{TM}} 100$ bp Plus DNA Ladder was used. Fragments were visualized under UV transilluminator and photographed.

\section{DArT and DArTseq ${ }^{\mathrm{TM}}$ analysis}

The microarray-based DArT and DArTseq ${ }^{\mathrm{TM}}$ assay were performed at Diversity Arrays Technology Pty Ltd. (DArT P/L), Canberra, Australia. Development of DArT markers followed methods published by Wenzl et al. (2004) and Tinker et al. (2009) and is described in detail by Kilian et al. (2012). DArTseq ${ }^{\mathrm{TM}}$ technology combining DArT with a next-generation sequencing technique was performed as in Courtois et al. (2013). DArTseq ${ }^{\mathrm{TM}}$ provided two types of markers: silicoDArT presence/absence variants (PAVs) and DArTseq single-nucleotide polymorphisms (SNPs).

\section{SCAR primer design and marker validation}

RAPD-PCR and SRAP-PCR products which differentiated the DNA pools were verified by tests on 20 random homozygous individuals, then extracted from agarose gels and purified using the GenElute ${ }^{\mathrm{TM}}$ Gel Extraction Kit (Merck). Purified DNA was cloned using the TOPO ${ }^{\circledR}$ TA Cloning ${ }^{\circledR}$ Kit for Sequencing (Invitrogen) and competent cells of $E$. coli strain $\mathrm{DH} 5 \alpha^{\mathrm{TM}}-\mathrm{T} 1^{\mathrm{R}}$. Plasmids were extracted from bacterial cells and used as a template for PCR with M13 forward/reverse primers. Products were subjected to Sanger sequencing at Genomed (Warsaw, Poland). Sequences were analyzed using BioEdit sequence alignment editor v. 7.0.5.3 (Hall 1999) and used to design the sequence-characterized amplified region (SCAR) primers with NCBI primer blast (Ye et al. 2012) as well as Primer3 software (Rozen and Skaletsky 2000).

DArT, silicoDArT and DArTseq markers with segregation patterns closest to the crown rust resistance phenotype in the studied population (Spearman's rank correlation $r<0.8 ; p$ $<0.001$ (Spearman 1904)) were chosen for further analysis. DNA sequences were analyzed to identify primer pairs for their amplification as above. The criteria for primer design were as follows: $40-60 \%$ GC rich; minimum annealing temperature, $50{ }^{\circ} \mathrm{C}$; and no or negligible secondary structures.

SCAR PCR was carried out in $10-\mu 1$ reactions. For RAPD-SCAR, DArT-SCAR and silicoDArT-SCAR, reactions contained $20 \mathrm{ng}$ of template DNA, $1 \times$ Taq PCR Buffer (750 mM Tris- $\mathrm{HCl}, \mathrm{pH} 8.8$ at $25^{\circ} \mathrm{C} ; 500 \mathrm{mM} \mathrm{KCl} ; 0.8 \%$ v/v Nonidet P-40; $1,25 \mathrm{mM} \mathrm{MgCl}_{2}$ ), 0.5 U Taq DNA polymerase, (Thermo Fisher Scientific), $0.1 \mathrm{mM}$ of each dNTP and $0.35 \mu \mathrm{M}$ of each forward and reverse oligonucleotide primer. The PCR thermal profile consisted of an initial hold at $94{ }^{\circ} \mathrm{C}$ for $3 \mathrm{~min}$, followed by 38 cycles of $94{ }^{\circ} \mathrm{C}$ for $25 \mathrm{~s}$, $58^{\circ} \mathrm{C}$ for $30 \mathrm{~s}$ and $72{ }^{\circ} \mathrm{C}$ for $1 \mathrm{~min} 10 \mathrm{~s}$, followed by a final hold at $72{ }^{\circ} \mathrm{C}$ for $5 \mathrm{~min}$. For SRAP-SCAR, reactions contained $20 \mathrm{ng}$ of template DNA, $1 \times$ Taq PCR Buffer $2 \mathrm{mM}$ $\mathrm{MgCl}_{2}, 0.6 \mathrm{U}$ DNA polymerase (DreamTaq ${ }^{\mathrm{TM}}$, Thermo Scientific), $0.2 \mathrm{mM}$ of each dNTP and $0.4 \mu \mathrm{M}$ of forward and reverse primers. For DArTseq, the polymerase was changed to JumpStart ${ }^{\mathrm{TM}} \mathrm{Taq}$ and the buffer was changed to JumpStart ${ }^{\mathrm{TM}}$ (Merck). Thermocycling conditions were as follows: an initial denaturation at $94^{\circ} \mathrm{C}$ for $5 \mathrm{~min}, 38$ cycles of $94^{\circ} \mathrm{C}$ for $30 \mathrm{~s}, 49^{\circ} \mathrm{C}$ for $30 \mathrm{~s}$ and $72{ }^{\circ} \mathrm{C}$ for $30 \mathrm{~s}$, ended with final extension at $72{ }^{\circ} \mathrm{C}$ for $5 \mathrm{~min}$. PCR products were visualized on agarose gels as described above.

The predictive ability for obtained PCR markers linked to the Pc39 gene was evaluated using a set of 22 oat cultivars (Table 4).

\section{Statistics}

Chi-squared $\left(\chi^{2}\right)$ analyses of the phenotyping data from $\mathrm{F}_{2}$ and $\mathrm{F}_{3}$ progeny were conducted in order to test the goodnessof-fit of observed to expected segregation ratios.

\section{Sequence data analysis}

Sequence homology searches were performed with the BLASTn at http://www.ncbi.nlm.nih.gov of the National Center for Biotechnology Information (NCBI) using the Nucleotide Collection Database. The threshold parameter was established at $10^{-7}$, with only hits with $E$ values below this cutoff considered as significant. BLASTn with basic 
search options was also performed at the T3/Oat web interface (https://triticeaetoolbox.org/oat/viroblast/viroblast.php) to assign positions of selected markers to the consensus map of Chaffin et al. (2016) and Bekele et al. (2018).

\section{Linkage analysis}

MapDisto 2.0 software (Lorieux 2012) was used to create a partial linkage group from the DNA marker data. Loci were placed into linkage groups using a minimum LOD (logarithm of odds) score of 3 and a maximum distance between markers of $30 \mathrm{cM}$. Individuals with $>20 \%$ of missing data were omitted. Marker order was determined with the Seriation II method based on the Seriation algorithm (Buetow and Chakravarti 1987) using the SARF (Sum of Adjacent Recombination Frequencies) criterion. Graphical linkage group presentation was generated using MapChart 2.32 Software (Voorrips 2002). Linkage groups were assigned to the oat consensus map of Chaffin et al. (2016) and Bekele et al. (2018).

\section{Results}

\section{Segregation of resistance to crown rust in the 'Celer'/STH9210 $F_{2}$ and $F_{2: 3}$ populations}

The $P$. coronata isolates used to assess segregation of $P c 39$ resistance gene were virulent to the STH9210 line and were avirulent on 'Celer.' Based on Chi-square tests, the segregation patterns fit a Mendelian ratio of three resistant/one susceptible genotype in $\mathrm{F}_{2}$ population and one homozygous resistant/two segregating/one homozygous susceptible genotypes in $\mathrm{F}_{3}$ population confirming a single gene hypothesis. The detailed results were $145 \mathrm{R}: 35 \mathrm{~S}$ with the 13.3/1 $P$. coronata isolate $\left(\chi^{2}=2.96 ; p\right.$ value $\left.=0.085\right) ; 144 \mathrm{R}: 34 \mathrm{~S}$ with 94.3/1 P. coronata isolate $\left(\chi^{2}=3.02 ; p\right.$ value $\left.=0.083\right)$ and $144 \mathrm{R}: 33 \mathrm{~S}$ with $107.2 / 3$ P. coronata isolate $\left(\chi^{2}=3.66 ; p\right.$ value $=0.056$ ). The isolates $13.3 / 1$ and $94.1 / 4$ used to screen $155 \mathrm{~F}_{2: 3}$ families both generated results of $49 \mathrm{R} / 70 \mathrm{H} / 36 \mathrm{~S}$ $\left(\chi^{2}=3.43 ; p\right.$ value $\left.=0.179\right)($ Table 2$)$.

\section{Bulked segregant analysis}

The 520 RAPD primers tested amplified a total of 5420 DNA products. Nineteen of these potentially differentiated resistant and susceptible hybrid pools in the 'Celer'/ STH9210 population. One-thousand twenty-four SRAP primers tested amplified 12,325 products, with 35 selected as generating polymorphic bands between the contrasting DNA bulks. Only two combinations (OPH11; Me23+Em14) were validated as amplifying products which matched the presence or absence of the $P c 39$ gene in 20 random individual plants. The primer OPH11 5'-CTTCCGCAGT-3' generated $\mathrm{a} \sim 1100 \mathrm{bp}$ DNA fragment which was present in the susceptible bulk and individuals as well as the STH9210 susceptible parent. SRAP primers Me23: 5'-TGAGTCCAAACC GGGAT-3' and Em14: 5'-GACTGCGTACGAATTCTA-3' generated a $~ 900$ bp DNA fragment present in the resistant bulk and individuals, Pc39 line and resistant parent 'Celer.' The PCR products were cloned and sequenced.

\section{Identification of DArT, DArTseq and silicoDArT markers correlated with Pc39 segregation pattern}

Six hundred ten DArT, 29430 DArTseq and 3600 silicoDArT markers had been generated, 15 of which (1 DArT and 14 silicoDArT) were highly correlated with the Pc39 dominant allele segregation pattern, whereas thirty-nine (3 DArTseq and 36 silicoDArT) corresponded to the Pc39 recessive allele segregation pattern (Supplemental Table 1).

\section{Sequence homology analysis}

Significant BLASTn hits at NCBI database were obtained for the SCAR_SRAP_Me23 + Em14 (907 nt). The sequence matched five regions of Avena strigosa accession DQ680849.1 containing beta-amyrin synthase (Sadl) and cytochrome P450 CYP51H10 ( $\mathrm{Sad} 2)$ genes sequences $(E$ value of $1 \mathrm{e}-165,92 \%$ query coverage) and showed a significant similarity to the Pc68LrkB1 (AY038003; three regions; $E$ value of $2 \mathrm{e}-137,92 \%$ query coverage), Pc68LrkB6 (AY038008; three regions; $E$ value of $0,92 \%$ query
Table 2 Segregation ratios of $\mathrm{F}_{2}$ progeny and $\mathrm{F}_{2: 3}$ families from the cross 'Celer'/STH9210 when inoculated with crown rust isolates $13.3 / 1 ; 94.1 / 4$ and $107.2 / 3$

\begin{tabular}{lcclllll}
\hline \multicolumn{2}{l}{ 'Celer'/STH9210 } & & & & & \\
\hline Generation & $\begin{array}{l}\text { Puccinia coro- } \\
\text { nata isolate }\end{array}$ & Resistant & Segregating & Susceptible & Ratio & $\chi^{2}$ & $p$ value \\
\hline $\mathrm{F}_{2}$ & $13.3 / 1$ & 145 & - & 35 & $3: 1$ & 2.963 & $0.08519^{*}$ \\
$\mathrm{~F}_{2: 3}$ & $13.3 / 1$ & 49 & 70 & 36 & $1: 2: 1$ & 3.431 & $0.17985^{*}$ \\
$\mathrm{~F}_{2}$ & $94.1 / 4$ & 144 & - & 34 & $3: 1$ & 3.019 & $0.0829^{*}$ \\
$\mathrm{~F}_{2: 3}$ & $94.1 / 4$ & 49 & 70 & 36 & $1: 2: 1$ & 3.431 & $0.17985^{*}$ \\
$\mathrm{~F}_{2}$ & $107.2 / 3$ & 144 & - & 33 & $3: 1$ & 3.659 & $0.05574^{*}$ \\
\hline
\end{tabular}

*Nonsignificant 
coverage), Pc68LrkCl (AY038009; two regions, $E$ value of 5e-158, 92\% query coverage) and Pc68LrkC3 (AY038011; two regions ( $E$ value of $2 \mathrm{e}-69,53 \%$ query coverage). These sequences are four subclones generated by sequencing of Pc68LrkB (12,467 bp) and Pc68LrkC (11,747 bp) clones isolated from the Pc68 line. The sequences contain retrotransposon and repetitive DNA linked to the ALrk receptor kinase gene.

BLASTn at the T3/Oat web revealed that silicoDArT 3455235 was highly similar to avgbs_cluster_32397.1.62, and 3,456,198 was homologous to avgbs2_122557.1.35. Both of those markers are localized on the position 3.7 of Mrg11 of oat consensus map. Additionally, 3455179 and 3455725 were highly similar to avgbs_246256.1.9 of Mrg 11 (6.7). SilicoDarT 3454180 was also highly similar to avgbs_88849.1.10 (Mrg11_6,1) (Supplemental Table 1; Fig. 1).

\section{SCAR marker design}

In order to increase the specificity and reproducibility of RAPD and SRAP markers, a set of SCAR primers was designed based on the sequenced DNA fragments (Table 3). Amplifications were carried out for the parents and the full set of 'Celer'/STH9210 $\mathrm{F}_{2}$ progeny. With SCAR_RAPD_ H11 primers (SCAR_RAPD_H11_F 5'-CTTCCGCAGTCT TACCTATTT-3'; SCAR_RAPD_H11_R 5'-CTTCCGCAG TGGTGTGGT-3'), a single specific band of $1111 \mathrm{bp}$ was amplified in susceptible parent STH9210 and most of the susceptible and heterozygous plants. The background DNA fragments amplified by the decamer primer OPH11 were no longer detected on the gel. With SCAR_SRAP primers (SCAR_SRAP_Me23 5'-ATGCTCGTCCCCTATCTTCA-3', SCAR_SRAP_Em14 5'-CGTACGAATTCTTTAC-3'), a DNA product of $707 \mathrm{bp}$ matching the segregation of the Pc39 dominant allele was amplified.

For DArT, DArTseq and silicoDArT markers meeting the criteria for primer design, pairs of SCAR primers were synthesized (Table 3). DArT SCAR_oPt_17172 marker co-segregated with the recessive susceptible Pc39 allele and silicoDArT SCAR_3456624, SCAR_3456272 and SCAR_3454401 co-segregated with the dominant resistant Pc39 allele.

\section{Linkage analysis and marker validation}

SCAR, DArT, DArTseq and silicoDArT markers linked to the $P c 39$ gene were used to create a partial linkage group (Fig. 1). Six PCR-based dominant markers were mapped from $0.37 \mathrm{cM}$ (SCAR_3456624) through $2.2 \mathrm{cM}$ (SCAR_ RAPD_H11), $5.3 \mathrm{cM}$ (SCAR_oPt_17172) to $12 \mathrm{cM}$ (SCAR_ SRAP_Me23+Em14; SCAR_3454401) from Pc39 (Fig. 1).
The best diagnostic marker for Pc39 was SCAR_3456624, identifying all tested oat cultivars which had a Pc39 gene donor in their pedigree (Table 4).

\section{Discussion}

DNA markers are a key element of modern genomics and a useful tool for resistance breeding, enabling fast and reliable gene identification at early stages of plant development. In this research to develop markers for Pc39, different molecular marker systems based on distinct polymorphism-detecting techniques were used.

The only marker for $P c 39$ identified to date was a RFLP marker cdo666 found in the Pendek3948 population and located $6 \mathrm{cM}$ away from the gene (Wight et al. 2004). This marker was present in Pendek3948 linkage groups 1 and 5. Group 1 shows homeology to KO37. Group 5 is homeologous to group 3, and both these groups show homeology to KO group 16_23 of the Kanota/Ogle genetic map (Wight et al. 2003), based on the single marker cdo1090d. RFLP marker systems require a complicated and costly procedure (Tanksley et al. 1989), which precludes high-throughput application. In this study, we have focused on the development of PCR-based markers for Pc39, which are simple to assay, requiring only a thermocycler and agarose gel electrophoresis. Markers linked with the Pc39 gene were successfully used for the development of six new PCR-based screens suitable for breeder selections. It is unlikely that one marker will be applicable across all tested germplasm, unless it directly differentiates alleles defining the trait, so the availability of multiple independent markers is desired. Use of the SCAR_RAPD_H11_F/R and oPt-17172_F/R primers allows the identification of the susceptible $P c 39$ allele, while primers SCAR_SRAP_Me23/Em14, 3456624_F/R, 3456272_F/R and 3454401_F/R can be used to identify the resistant $P c 39$ allele. All developed markers are dominant so that simultaneous detection of both alleles in a single reaction using multiplex PCR will allow selection of heterozygote genotypes (Elnifro et al. 2000; Hayden et al. 2008).

The availability of the consensus map of Chaffin et al. (2016) and the subsequent version of Bekele et al. (2018) significantly simplified gene mapping to linkage groups. Genome-wide association mapping of crown rust resistance in elite oat germplasm (Klos et al. 2017) confirmed previously determined locations of $P c 38$ (Mrg02 chromosome 9D) and Pc48 (Mrg20) (Wight et al. 2004) as well as Pc58a (Mrg02; Hoffman et al. 2006; Jackson et al. 2007), Pc68 (Mrg19; Kulcheski et al. 2010), Pc71 (Mrg21; Bush and Wise 1998) and Pc91 (translocated chromosome 7C-17A, Mrg18, Mrg28; Gnanesh et al. 2013). Continuous progress in chromosome localization of $P c$ genes enables the development of genomic tools in oat breeding but also facilitates 
Table 3 DNA sequences used for SCAR makers design

\begin{tabular}{|c|c|c|}
\hline Sequence name & Sequence $\left(5^{\prime}-3^{\prime}\right)$ & $\begin{array}{l}\text { Annealing } \\
\text { temp. }\left({ }^{\circ} \mathrm{C}\right)\end{array}$ \\
\hline CAR_RAPD_H11 & $\begin{array}{l}\text { CTTCCGCAGTCTTACCTATTTTGTAGTCACATTTATTTCGTTTGGAAAAGCTACCTCTACCATGTG } \\
\text { CACCAAGTACTGCACCTACTATGCCTGTTTCTTTCGGCATGTAAAAGAACAACTCAGGTAAGT } \\
\text { ACGTACGTACTGTACGTGCTAGCTGAAGATGATCGTGGTTGTGTGCGTCGCCATGATATCCTC } \\
\text { GGTCTCGTCTTCACCGGGTGCGTAGTCTTTGCGCTTGTATACTTTCACCACGAGTTGCTAGGG } \\
\text { AGTTGCCGAACACGCCCTACGTTCTAATTGCCCTCCCAAGCTATCACCCTCCTTCCTTCCTGA } \\
\text { GACAGAATCTTTAATCGACACCTAAAAATCTTTAATTGGCCAGATGAATAGTACATCTTAAAC } \\
\text { AAAGTCTACACACATTATCTCTCTACCTTTTTATTTGAAAAGAATATGGATGTCCCTATCACCGA } \\
\text { TCTATTTTTAAGCTAACTAGCAGCGACTCGGTGCACTGAATACCAACGAAGCCAAGAGCGAGG } \\
\text { AGTACGTAGGAAACGCACCGCCTACGATGCGTGTTGTCCTAGCAAACCGATAAGTAATGGAAC } \\
\text { ATGTGCCGTTTATAACAGTCATAGTACTATGTACAATAGTTTACACGTATACATTAACATTATCTT } \\
\text { CACATATGGAACTCAGTTGACACCTAGCTAAAATTCTTGAATTTGTCAGATGAATAGTTACATCTT } \\
\text { AAACAAAGTCTACACGCAATATCTGCCTACCTTTTATTTTAAAAAAGAATATTGTCATTGATGTTA } \\
\text { CACTCATGCCCCCATCACCGATCTATCTTTATTTTGAGAAAGAATATATTGTCATATCGACTCGAT } \\
\text { GCACTGAATTCCAACCAAGCTGCCAAGACCAAGAGTGAGGAGTAGGATGCACCACGTATGTAC } \\
\text { GATAAGTAATAAAATACGTGCCATTTATAATAATATTCGTAGATTACACGTGTACATTAACATTAT } \\
\text { CTTCATGTTTGGAACTCGGTACTGCTAGTCAATCGTAGCCTAATAAATTAGGCAGAGGTTGCT } \\
\text { TGTTTGACCTGATCGCATCCACTCTCTATAAAATACGGCACCCTACTGATGCCKCCTTGTACAA } \\
\text { ACCACACCACTGCGGAAG }\end{array}$ & 58 \\
\hline SCAR_SRAP & $\begin{array}{l}\text { TTATGTYCAAACKCGGGATATCTCAAAACATTTCSGTMCATSCCGGGGTAAAAAAGGACAAAA } \\
\text { TGTCTGCCGAATCGGTAGGAAGTGGGTCCGGTTTGTATACAGGTACATGATCTAACGCCCGT } \\
\text { GATTTTTTGAAAAAAAACATTTTTAGACTCACAATATGTGGTTTCTTCAGAGATCCAATGCAA } \\
\text { GTTCTAATGATGCTCGTCCCCTATCTTCATGCACGCCGGTTCGACCTTAGTTCGAAAAGGGA } \\
\text { AAAATTCAAAGCAGGCATAAGATATTCAAAAAAGTTCGAACAATGTAAATCCTTCGTGTGGTG } \\
\text { TCATATTATGTGACATAGTTGCAAGGAAAAATGCCAGACTTGGTATATTGATCATCTCTCGAA } \\
\text { AAAACCTTCACAAAATGACCTGTCATGTTCGAGGTTTCATGGCTTTCGGTCAAATGACCAATG } \\
\text { TTATGTGCTGAATCGCGGCATAGTTTATGATATTGTGCCCATATTATGCATGTATGTGGAAATTGG } \\
\text { GATGGAGCACAATGTTGCAGGAGGAAGTTTTCCTTTTCGTTACACGGAAAAGCCATTTTCCAT } \\
\text { TTTCCGAGCGCAAAAAACGGGTCGTTTTGTAAAGCAACCACCAAAATGCTGTTTCAGAATGCT } \\
\text { ACCGTCCCATTTTCTAAAATACTAGACCACCTTACATGGACTATCCTCCAACCGGGATATCTCAA } \\
\text { ACTTTTCCGTCCATCCCAGGTAAAAAGGATAAATTTCTACCGAATCAGTAGGAAGTAGGGTTT } \\
\text { GTACTACAGATACATGATCTAACGCCCGTGATTTTTTGAAAAAATCATTTTTAGACTCGCAATATG } \\
\text { TGGATTCTTTAGAGATCCAATGCAAGTTCTAAATAAGAAATAAGCCCATTTAGTCCCGGTTGGTA } \\
\text { AAGAATTCGTACGCA }\end{array}$ & 52 \\
\hline oPt-17172 & $\begin{array}{l}\text { TGCAGGCACAACCGACATTCCTATGCATCCTTTGTCCCATCAGGAAACGGTCCATCTATGTTCACC } \\
\text { CTGACAAAACCGGCAGGAGGACGAGTACATTTTGAAACGTGGGTTATGCTCGGCGCACTCTT } \\
\text { CAGGGTGCAGAGTTCTTTCTATTCAGCGACATATCTTGTAATCTGATACAGAAATTCACCAAC } \\
\text { TCCTGTAAGAGACTCAACATGGTTTGCCTTATTGTGCTGCACCCAAAACAGAGGAAACAGAGT } \\
\text { GAGCGCTACTGTAGCTCATCCGACAATGCGAATATGCTCGCCAAAATTCTCATTGCACAATAA } \\
\text { AAGTTCCTGACGGATACCCGTCCGTTAAGCTGCTAACCACGTCTTCTTCACCTCATTGCACAT } \\
\text { CATGCCCAAACTGTACTGACTGTAATGATGCGTAATAGTCAGACGTTCGGTAGAACTCTTAAT } \\
\text { CCTGATAGATATTACAGTCACAGAGCAGGTATAGCTATTTACAGATGGGTTCCCGGTTAGAGAGT } \\
\text { ACGCGGCGTCTGCA }\end{array}$ & 65 \\
\hline 3456624 & $\begin{array}{l}\text { TGCAGTGAGCTAGTTTAGTTCATCTGCGTCGTCGTTAGAGACTCTGGATTCATGCTTGAACGA } \\
\text { CGTAGT }\end{array}$ & 58 \\
\hline 3456272 & $\begin{array}{l}\text { TGCAGCAGGTATGGAAGTGACGTCGCACCGCGCTGTCAATTCAGCCGAGATCGGAAGAGCGGT } \\
\text { TCAGCA }\end{array}$ & 65 \\
\hline 3454401 & $\begin{array}{l}\text { TGCAGAGGAGTTGCTACTAGTACATGGAAATGAATCTCCTCTGCTTGGCACTTCTTCCCGT } \\
\underline{\text { GAAGGCCC }}\end{array}$ & 56 \\
\hline
\end{tabular}

The bold, underlined regions are the sequences used for SCAR marker design. Annealing temperature for each primer set is given in the last column

the characterization of allelic relationships of these genes. Because of the highly dynamic nature of $P$. coronata populations, race-specific crown rust resistance can be easily overcome, creating an urgent need to identify new effective sources of resistance. Confirmation that sources do represent novel variation is difficult without information about the genomic location of existing $P c$ genes. For example, a seedling resistance gene identified in the oat cultivars Kame and Morton (McMullen et al. 2005; Gnanesh et al. 2015) was described as a locus, $P c K M$, and was placed on Mrg08 between 80.2 and $81.4 \mathrm{cM}$ (chromosome 12D). Recent studies of Kebede et al. (2019) showed that Pc45 has the same 


\section{Pc39_linkage_map}

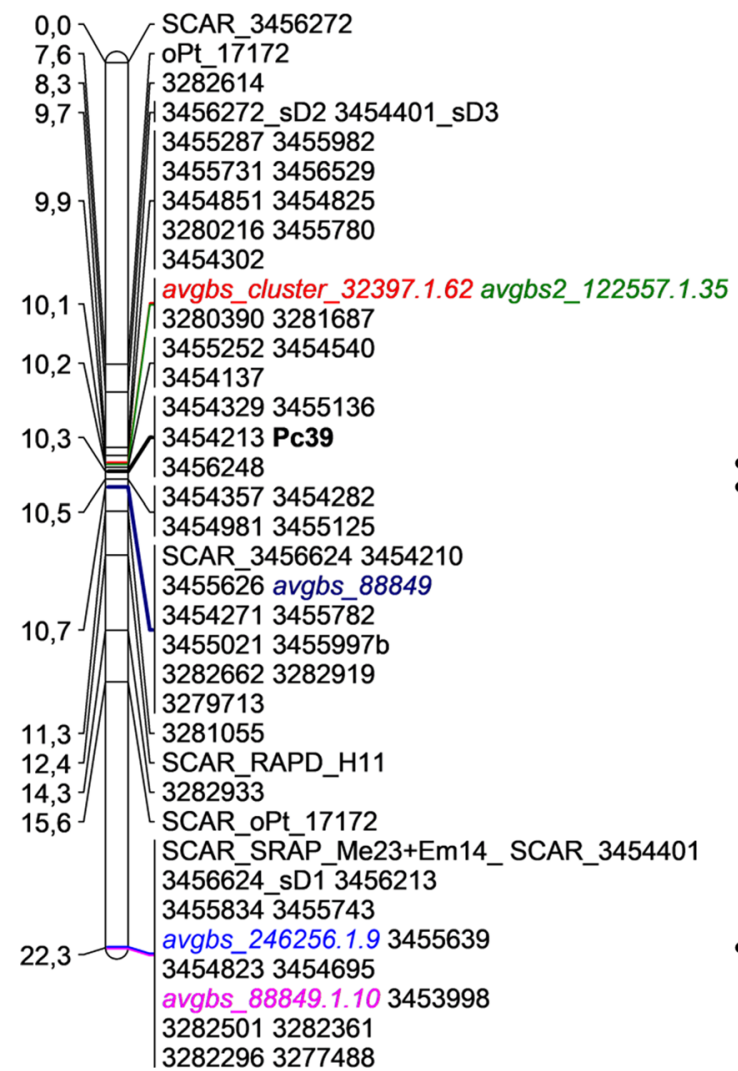

Fig. 1 Partial linkage map of markers for Pc39 gene and its assignment to Mgr11 group of the oat consensus map developed by Chaffin et al. (2016) and saturated by Bekele et al. (2018). Pc39 linkage map contains DArT (oPt_), DArTseq (marked with numbers) and

location as $P c K M$, suggesting that these are the same genes. Moreover, Admassu-Yimer et al. (2018), thanks to expanded consensus map data availability, were also able to place $P c 53$ in close proximity to this gene $(\mathrm{Mrg} 08,82.4 \mathrm{cM})$, suggesting that $P c 53$ and $P c 45$ may be components of a gene complex in this region conditioning resistance to $P$. coronata.

Many $P c$ genes presumably occur in clusters (Harder et al. 1980; Martens et al. 1980; Chong et al. 1994; Chong and Brown 1996; Leonard et al. 2005). Development of molecular markers for one of the $P c$ genes could determine its location in the genome and may facilitate the study of other genes present in the same cluster or may allow it to be distinguished from flanking loci. According to Kiehn et al. (1976) $P c 39$ gene is clustered with $P c 55$, while Leonard et al. (2005) hypothesize that $P c 39, P c 55$ and $P c 71$ are alleles of the same gene. Wight et al. (2004) suggest that Pc39 may be present on KO group 16_23, which according to Chaffin et al. (2016) is homeologous to Mrg24 of consensus map of oat or KO37 equivalent to Mrg11. In this study, we used all identified marker sequences co-segregating with

\section{Consensus_map_Mrg_11}

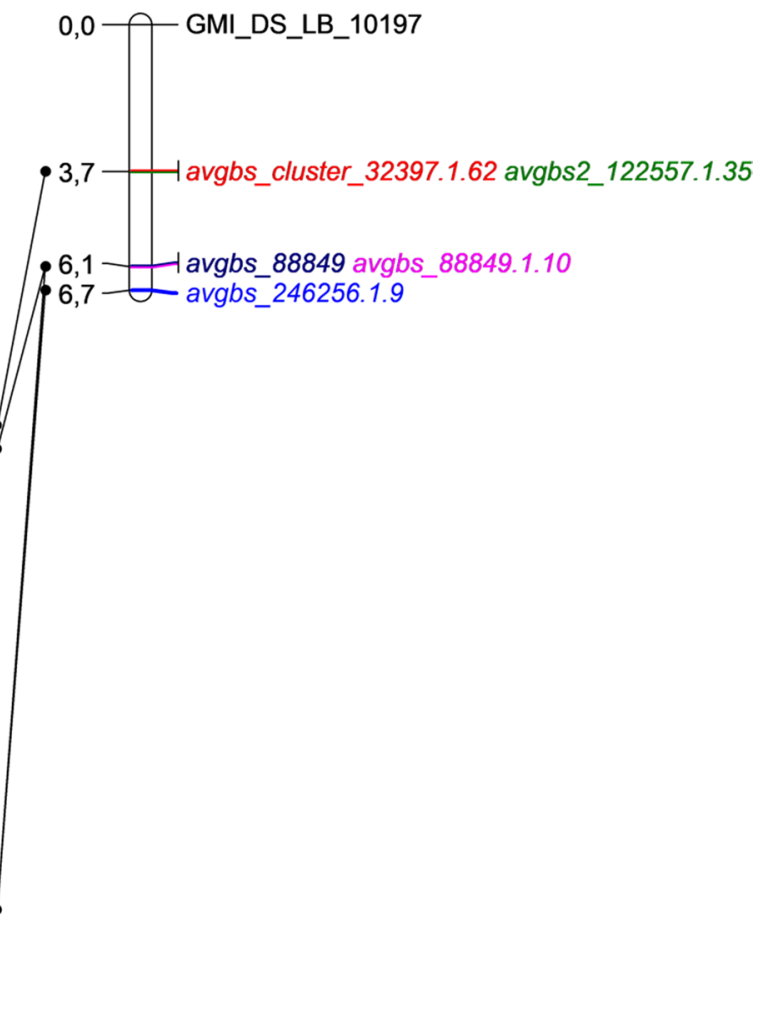

silicoDArT (_sD) markers for Pc39 gene as well as SCAR (sequencecharacterized amplified region) markers based on DArT (SCAR oPt_), DArTseq (SCAR_), RAPD-PCR (SCAR_RAPD), SRAP-PCR (SCAR_SRAP) products correlated with $P c 39$ segregation pattern

Pc39 to perform BLASTn at the T3/Oat web interface to assign the approximate $P c 39$ positions on the consensus map of oat. Our data showed that $P c 39$ is linked with markers placed on the Avena consensus linkage group Mrg11 at 3.7 to $6.7 \mathrm{cM}$. The closest marker, SCAR_3456624, is also the best diagnostic marker, allowing the identification of the Pc39 dominant allele in all tested oat cultivars having $P c 39$ in their pedigree. Linkage with crown rust resistance has not been previously reported for this genomic region; however, Klos et al. (2017) detected a QTL for crown rust reaction on $\operatorname{Mrg} 11$ at 16.2 to $21.9 \mathrm{cM}$ in the spring oat panel. This experiment used a set of eight isolates virulent against $P c 39$, so the identified region could not be associated with the $P c 39$ gene. According to Bush and Wise (1998), $P c 71$ is located on Mrg21 which excludes the possibility that $P c 39$ and $P c 71$ are alleles of the same gene.

BLASTn against the NCBI database did not show the significant sequence similarity for any of the analyzed markers, which may be due to the lack of the sequence available for 


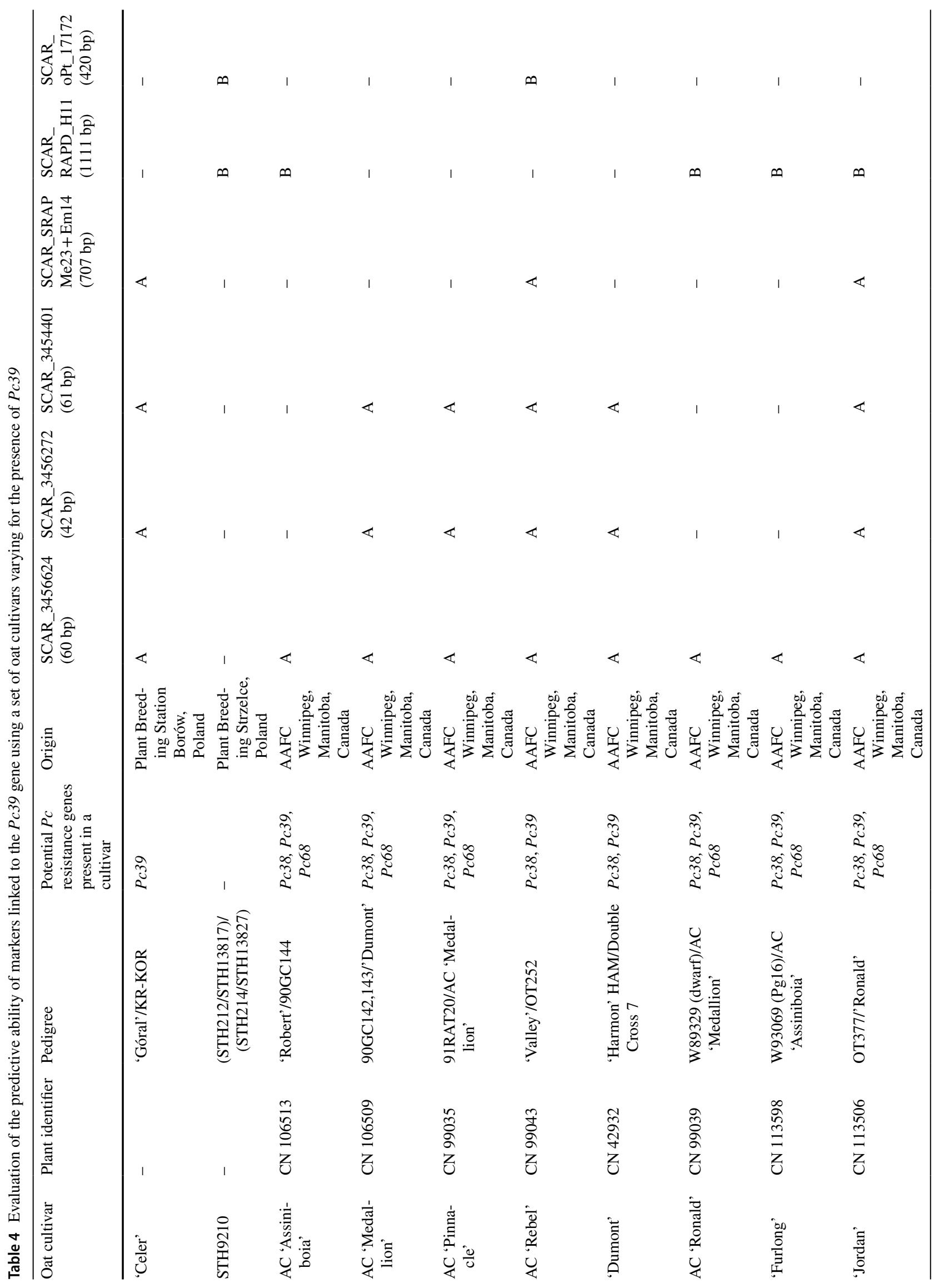




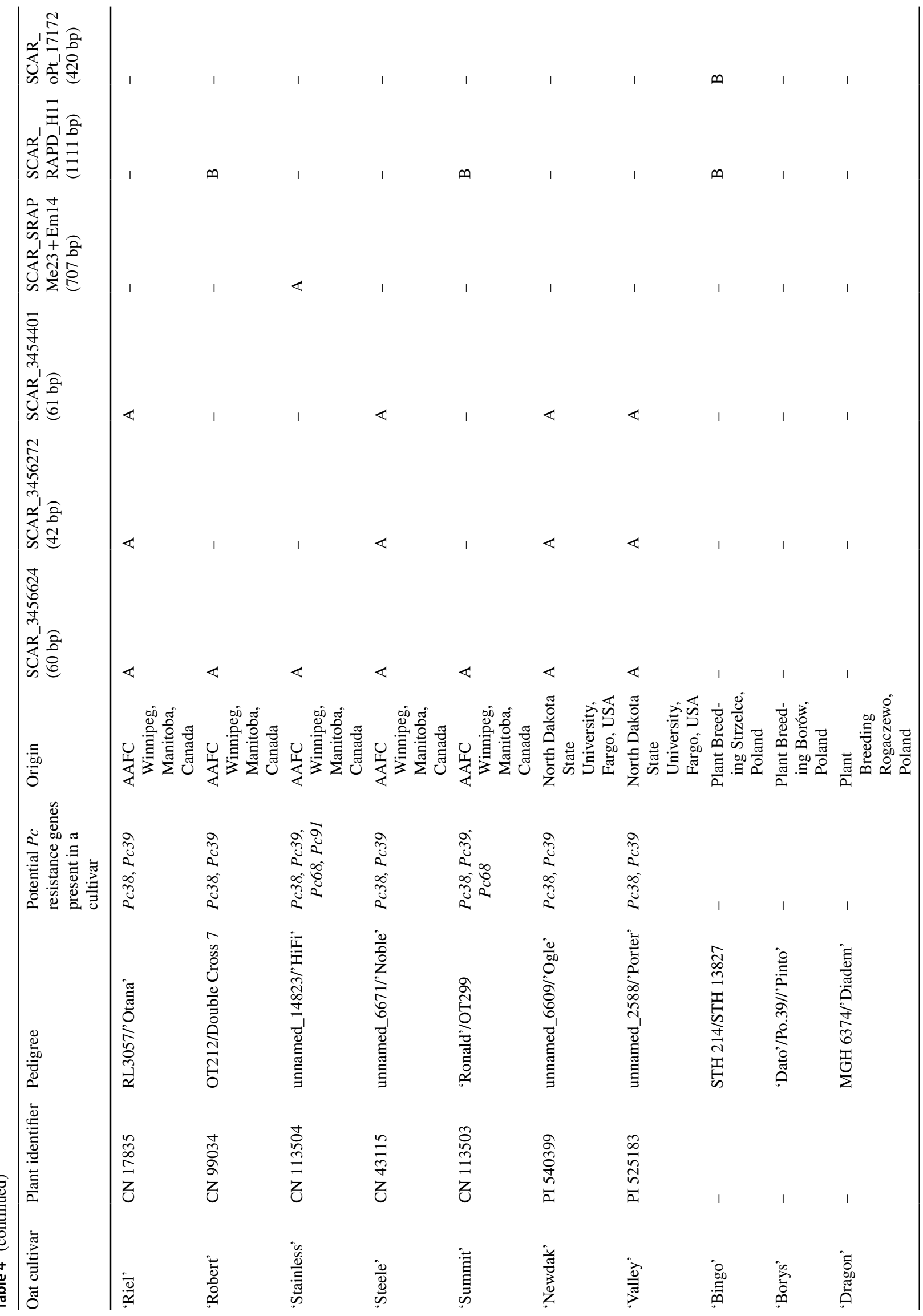




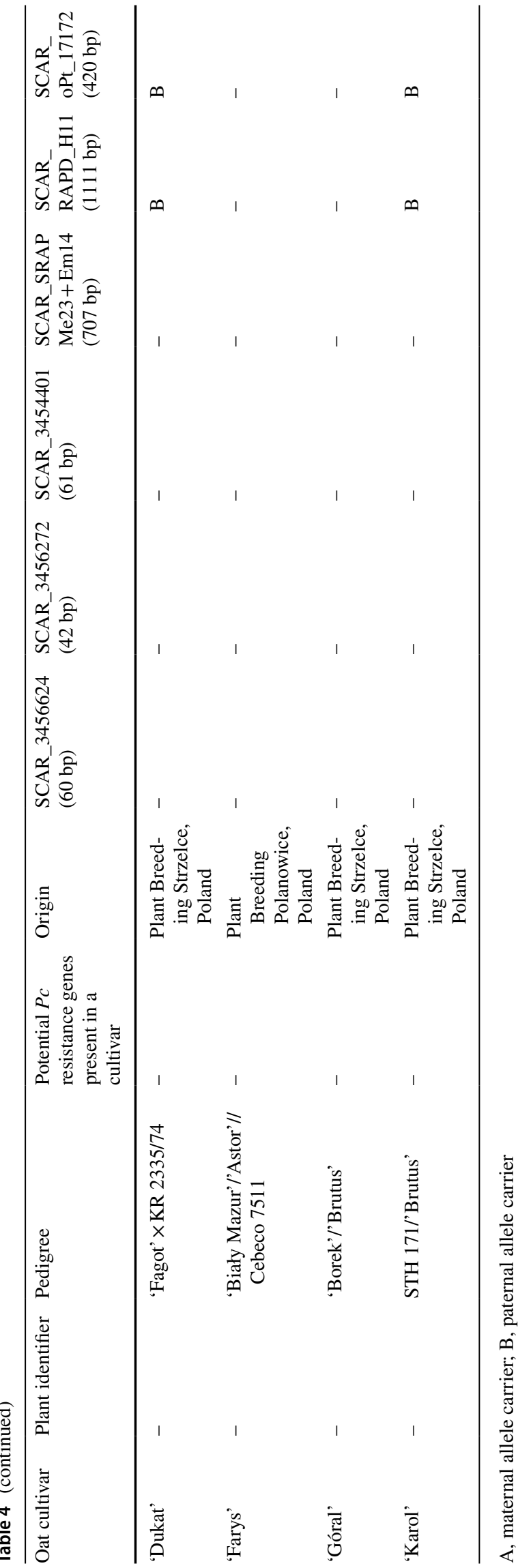

the Avena sativa genome, which in turn significantly limits the ability to identify candidate genes for $P c 39$.

Expanding knowledge of the genetics of host resistance is a key to resistant cultivar development. The large and complex oat genome structure, with its high proportion of repetitive elements, pseudogenes, low gene density and polyploidy, poses a serious challenge to oat improvement. The newly developed PCR-based markers for Pc39 are closely linked to the gene and bracket the locus. They will support effective gene introgression and facilitate fine mapping and positional cloning. Such study may also contribute toward better understanding of crown rust resistance mechanisms in oat and provide insight into genes function, as none of the $P c$ genes has been cloned to data.

Acknowledgements The authors are grateful to Prof. Krzysztof Kowalczyk, Director of Institute of Plant Genetics, Breeding and Biotechnology, University of Life Sciences in Lublin, Poland, for his comments to improve the research. We also thank Dr Tim Langdon (Institute of Biological, Environmental and Rural Sciences, Aberystwyth University, Aberystwyth, UK) for critical review of this manuscript prior to submission.

Author contribution statement EPG designed the research. EPG and SS performed experiment and analyzed the data. SS wrote the manuscript with contribution from EPG. Both authors approved the final version of manuscript.

Funding This work was supported by the Ministry of Agriculture and Rural Development Grant 'Crown rust resistance genes pyramiding in oat genome and identification of DNA markers for these genes' (No. HOR.hn.802.8.2014).

\section{Compliance with ethical standards}

Conflict of interest The authors declare that they have no conflict of interest.

Open Access This article is licensed under a Creative Commons Attribution 4.0 International License, which permits use, sharing, adaptation, distribution and reproduction in any medium or format, as long as you give appropriate credit to the original author(s) and the source, provide a link to the Creative Commons licence, and indicate if changes were made. The images or other third party material in this article are included in the article's Creative Commons licence, unless indicated otherwise in a credit line to the material. If material is not included in the article's Creative Commons licence and your intended use is not permitted by statutory regulation or exceeds the permitted use, you will need to obtain permission directly from the copyright holder. To view a copy of this licence, visit http://creativecommons.org/licenses/by/4.0/.

\section{References}

Admassu-Yimer B, Bonman JM, Klos KE (2018) Mapping of crown rust resistance gene Pc53 in oat (Avena sativa). PLoS ONE 13:e0209105. https://doi.org/10.1371/journal.pone.0209105

Bekele WA, Wight CP, Chao S, Howarth CJ, Tinker NA (2018) Haplotype based genotyping-by-sequencing in oat genome research. 
Plant Biotechnol J 16:1452-1463. https://doi.org/10.1111/ pbi. 12888

Budak H, Shearman RC, Parmaksiz I, Gaussoin RE, Riordan TP, Dweikat I (2004) Molecular characterization of buffalograss germplasm using sequence-related amplified polymorphism markers. TAG 108:328-334

Buetow KN, Chakravarti A (1987) Multipoint gene mapping using seriation. Am J Hum Genet 41:189-201

Bush AL, Wise RP (1998) High-resolution mapping adjacent to the Pc71 crown-rust resistance locus in hexaploid oat. Mol Breed 4:13-21. https://doi.org/10.1023/A:1009652222382

Cabral AL, Gnanesh BN, Fetch JM, McCartney C, Fetch T, Park RF, Menzies JG, McCallum B, Nanaiah GK, Goyal A (2014) Oat fungal diseases and the application of molecular marker technology for their control. In: Goyal A, Manoharachary C (eds) Future challenges in crop protection against fungal pathogens. Springer, New York, pp 343-358

Carson ML (2009) Broad-spectrum resistance to crown rust, Puccinia coronata f. sp. avenae, in accessions of the tetraploid slender oat, Avena barbata. Plant Dis 93:363-366

Carson ML (2011) Virulence in oat crown rust (Puccinia coronata f. sp. avenae) in the United States from 2006 through 2009. Plant Dis 95:1528-1534. https://doi.org/10.1094/PDIS-09-10-0639

CDL (2018) Cereal Disease Laboratory. Resist genes. https://www.ars. usda.gov/midwest-area/stpaul/cereal-disease-lab/docs/resistance -genes/resistance-genes/. Accessed 4 Oct 2018

Chaffin AS, Huang Y, Smith S, Bekele WA, Gnanesh BN, Foresman BJ, Blanchard SG, Jeremy J, Reid RW, Wight CP, Chao S, Oliver R, Kolb FL, Mccartney C, Mitchell JW, Beattie AD, Bjørnstad Å, Bonman JM, Langdon T, Howarth CJ, Cory R, Jellen EN, Esvelt K, Poland JA, Hsieh T, Brown R, Jackson E, Schlueter JA, Tinker NA (2016) A consensus map in cultivated hexaploid oat reveals conserved grass synteny with substantial sub-genome rearrangement. Plant Genome 9(2):1-35. https://doi.org/10.3835/ plantgenome2015.10.0102

Chen Q, Armstrong K (1994) Genomic in situ hybridization in Avena sativa. Genome 37:607-612

Chong J, Brown PD (1996) Genetics of resistance to Puccinia coronata f. sp. avenae in two Avena sativa accessions. Can J Plant Pathol. https://doi.org/10.1080/07060669609500626

Chong J, Howes NK, Brown PD, Harder DE (1994) Identification of the stem rust resistance gene $P g 9$ and its association with crown rust resistance and endosperm proteins in "Dumont" oat. Genome 37:440-447

Chong J, Gruenke J, Dueck R, Mayert W, Mitchell Fetch JW, McCartney CA (2011) Virulence of Puccinia coronata f. sp. avenae in the eastern prairie region of Canada during 2007-2009. Can J Plant Pathol 33:77-87. https://doi.org/10.1080/07060661.2010.546957

Courtois B, Audebert A, Dardou A, Roques S, Ghneim-Herrera T, Droc G, Frouin J, Rouan L, Gozé E, Kilian A, Ahmadi N, Dingkuhn M (2013) Genome-wide association mapping of root traits in a japonica rice panel. PLoS ONE 8:1-18. https://doi.org/10.1371/ journal.pone.0078037

Cox TS, Raupp WJ, Gill BS (1993) Leaf rust-resistance genes Lr41, Lr42 and Lr43 transferred from Triticum tauschii to common wheat. Crop Sci. https://doi.org/10.2135/cropsci1994.00111 83X003400020005x

Elnifro EM, Ashshi AM, Cooper RJ, Klapper PE (2000) Multiplex PCR: optimization and application in diagnostic virology. Clin Microbiol Rev 13:559-570

Fleischmann G, McKenzie RIH (1968) Inheritance of crown rust resistance in Avena sterilis L. Crop Sci 8:710-713

Gnanesh BN, Mitchell Fetch JW, Menzies JG, Beattie AD, Eckstein PE, McCartney CA (2013) Chromosome location and allele-specific PCR markers for marker-assisted selection of the oat crown rust resistance gene $P c 91$. Mol Breed 32:679-686. https://doi. org/10.1007/s11032-013-9900-6

Gnanesh BN, McCartney CA, Eckstein PE, Mitchell Fetch JW, Menzies JG, Beattie AD (2015) Genetic analysis and molecular mapping of a seedling crown rust resistance gene in oat. Theor Appl Genet 128:247-258. https://doi.org/10.1007/s00122-014-2425-5

Gutierrez-Gonzalez JJ, Garvin DF (2011) Reference genome-directed resolution of homologous and homeologous relationships within and between different oat linkage maps. Plant Genome J 4:178. https://doi.org/10.3835/plantgenome2011.01.0004

Hall TA (1999) BioEdit: a user-friendly biological sequence alignment editor and analysis program for Windows 95/98/NT. Nucleic Acids Symp Ser 41:95-98

Harder DE, McKenzie RIH, Martens JW (1980) Inheritance of crown rust resistance in three accessions of Avena sterilis. Can J Genet Cytol 22:27-33. https://doi.org/10.1139/g80-005

Hayden MJ, Nguyen TM, Waterman A, Chalmers KJ (2008) Multiplexready PCR: a new method for multiplexed SSR and SNP genotyping. BMC Genom 9:1-12. https://doi.org/10.1186/1471-2164-9-80

Hittalmani S, Parco A, Mew TV, Zeigler RS, Huang N (2000) Fine mapping and DNA marker-assisted pyramiding of the three major genes for blast resistance in rice. Theor Appl Genet 100:1121-1128

Hoffman DL, Chong J, Jackson EW, Obert DE (2006) Characterization and mapping of a crown rust resistance gene complex (Pc58) in TAM O-301. Crop Sci 46:2630-2635. https://doi.org/10.2135/ cropsci2006.01.0014

Hsam SLK, Peters N, Paderina EV, Felsenstein F, Oppitz K, Zeller FJ (1997) Genetic studies of powdery mildew resistance in common oat (Avena sativa L.) I. Cultivars and breeding lines grown in Western Europe and North America. Euphytica 96:421-427

Huang N, Angeles ER, Domingo J, Magpantay G, Singh S, Zhang Q, Kumaravadivel N, Bennett J, Khush GS (1997) Pyramiding of bacterial blight resistance genes in rice: marker-assisted selection using RFLP and PCR. Theor Appl Genet 95:313-320

Jackson EW, Obert DE, Menz M, Hu G, Avant JB, Chong J, Bonman JM (2007) Characterization and mapping of oat crown rust resistance genes using three assessment methods. Phytopathology 97:1063-1070. https://doi.org/10.1094/PHYTO-97-9-1063

Jellen EN, Gill BS, Cox TS (1994) Genomic in situ hybridization differentiates between A/D- and C-genome chromatin and detects intergenomic translocations in polyploid oat species (genus Avena). Genome 37:613-618

Jellen EN, Rines HW, Fox SL, Davis DW, Phillips RL, Gill BS (1997) Characterization of "Sun II" oat monosomics through C-banding and identification of eight new "Sun II" monosomics. Theor Appl Genet 95:1190-1195. https://doi.org/10.1007/s001220050680

Jiráková H, Hanzalová A (2008) Crown rust pathotypes determined on oats in the Czech Republic from 2004 to 2006 and reaction to oat cultivars. Czech J Genet Plant Breed 2:60-65

Joshi RK, Nayak S (2010) Gene pyramiding-A broad spectrum technique for developing durable stress resistance in crops. Biotechnol Mol Biol Rev 5:51-60

Kebede AZ, Friesen-Enns J, Gnanesh BN, Menzies JG, Fetch JWM, Chong J, Beattie AD, Paczos-Grzęda E, McCartney CA (2019) Mapping oat crown rust resistance gene $P c 45$ confirms association with PcKM. G3-Genes Genomes Genet 9:505-511. https://doi. org/10.1534/g3.118.200757

Kiehn FA, McKenzie RIH, Harder DE (1976) Inheritance of resistance to Puccinia coronata avenae and its association with seed characteristics in four accessions of Avena sterilis. Can J Genet Cytol 18:717-727

Kilian A, Wenzl P, Huttner E, Carling J, Xia L, Blois H, Caig V, Heller-Uszynska K, Jaccoud D, Hopper C, Aschenbrenner-Kilian M, Evers M, Peng K, Cayla C, Hok P, Uszynski G (2012) Diversity arrays technology: a generic genome profiling technology on open 
platforms. In: Pompanon F, Bonin A (eds) Data production and analysis in population genomics: methods and protocols, methods in molecular biology. Springer, New York, pp 67-89

Klos KE, Yimer BA, Babiker EM, Beattie AD, Bonman JM, Carson ML, Chong J, Harrison SA, Ibrahim AMH, Kolb FL, McCartney CA, McMullen M, Fetch JM, Mohammadi M, Murphy JP, Tinker NA (2017) Genome-wide association mapping of crown rust resistance in oat elite germplasm. Plant Genome 10:2. https ://doi.org/10.3835/plantgenome2016.10.0107

Kordrostami M, Rahimi M (2015) Molecular markers in plants: concepts and applications. Genet 3rd Millenium 13:4022-4029. https ://doi.org/10.1017/cbo9781107415324.004

Kulcheski FR, Graichen FAS, Martinelli JA, Locatelli AB, Federizzi LC, Delatorre CA (2010) Molecular mapping of Pc68, a crown rust resistance gene in Avena sativa. Euphytica 175:423-432. https://doi.org/10.1007/s10681-010-0198-8

Leggett JM, Markhand GS (1995) The genomic identification of some monosomics of $A$. sativa $\mathrm{L}$. cv. Sun II using genomic in situ hybridization. Genome 38:747-751

Leonard KJ, Anikster Y, Manisterski J (2005) Virulence associations in oat crown rust. Phytopathology 95:53-61. https://doi.org/10.1094/ PHYTO-95-0053

Li G, Quiros CF (2001) Sequence-related amplified polymorphism (SRAP), a new marker system based on a simple PCR reaction: its application to mapping and gene tagging in Brassica. TAG Theor Appl Genet 103:455-461. https://doi.org/10.1007/s001220100570

Liu J, Liu D, Tao W, Li W, Wang S, Chen P, Cheng S, Gao D (2000) Molecular marker-facilitated pyramiding of different genes for powdery mildew resistance in wheat. Plant Breed 119:21-24. https://doi.org/10.1046/j.1439-0523.2000.00431.x

Lorieux M (2012) MapDisto: fast and efficient computation of genetic linkage maps. Mol Breed 30:1231-1235. https://doi.org/10.1007/ s11032-012-9706-y

Martens JW, McKenzie RIH, Harder DE (1980) Resistance to Puccinia graminis avenae and $P$. coronate avenae in the wild and cultivated Avena populations of Iran, Iraq, and Turkey. Can J Genet Cytol 22:641-649. https://doi.org/10.1139/g80-070

McCartney CA, Stonehouse RG, Rossnagel BG, Eckstein PE, Scoles GJ, Zatorski T, Beattie AD, Chong J (2011) Mapping of the oat crown rust resistance gene $P c 91$. Theor Appl Genet 122:317-325. https://doi.org/10.1007/s00122-010-1448-9

McMullen MS, Doehlert DC, Miller JD (2005) Registration of 'Morton' oat. Crop Sci 45:1664-1665

Menzies JG, Xue A, Gruenke J, Dueck R, Deceuninck S, Chen Y (2019) Virulence of Puccinia coronata var avenae f. sp. avenae (oat crown rust) in Canada during 2010 to 2015. Can J Plant Pathol. https://doi.org/10.1080/07060661.2019.1577300

Michelmore RW, Paran I, Kesseli RV (1991) Identification of markers linked to disease-resistance genes by bulked segregant analysis: a rapid method to detect markers in specific genomic regions by using segregating populations. Proc Natl Acad Sci USA 88:9828-9832

Murphy HC (1935) Physiologic specialisation in Puccinia coronata f. sp. avenae. Bull US Dept Agric 433:1-48

Nazareno ES, Li F, Smith M, Park RF, Kianian SF, Figueroa M (2018) Puccinia coronata f. sp. avenae: a threat to global oat production. Mol Plant Pathol 19:1047-1060. https://doi.org/10.1111/ mpp. 12608

Paczos-Grzęda E, Sowa S (2019) Virulence structure and diversity of Puccinia coronata f. sp. avenae P. Syd. \& Syd in Poland during 2013-2015. Plant Dis. https://doi.org/10.1094/pdis-10-18-1820-re

Penner GA, Chong J, Wight CP, Molnar SJ, Fedak G (1993) Identification of an RAPD marker for the crown rust resistance gene $P c 68$ in oats. Genome 36:818-820

Rajhathy T, Thomas H (1974) Cytogenetics of oats. Misc Publ Genet Soc Can 2:1-90
Rooney WL, Rines HW, Phillips RL (1994) Identification of RFLP markers linked to crown rust resistance genes $P c 91$ and $P c 92$ in oat. Crop Sci 34:940-944. https://doi.org/10.2135/cropsci199 4.0011183X003400040019x

Rozen S, Skaletsky H (2000) Primer3 on the www for general users and for biologist programmers. Methods Mol Biol 132:365-386

Šebesta J (1983) Race-specific expression of oat crown rust resistance conditioned by major and minor genes. Euphytica 32:857-861. https://doi.org/10.1007/BF00042167

Šebesta J, Zwatz B, Harder DE, Corazza L, Stojanovic S (1997) Incidence of crown rust and virulence of Puccinia coronata on oat and the effectiveness of $P c$-genes for resistance in Europe during 1990-1994. Arch Phytopathol Plant Prot 30:507-518. https://doi. org/10.1080/03235409709383204

Šebesta J, Zwatz B, Roderick H, Corazza L, Manisterski J, Stojanovic S (2003) Incidence of crown rust and virulence of Puccinia coronata cda. f. sp. avenae eriks. and the effectiveness of $P c$ genes for resistance in Europe, Middle East and North Africa. Arch Phytopathol Plant Prot 36:179-194. https://doi.org/10.1080/03235 400310001604071

Simons MD (1985) Crown rust. In: Roelfs AP, Bushnel WR (eds) The cereal rust, vol 2. Diseases, distribution, epidemiology, and control. Academic Press, Orlando, pp 131-172

Sowa S, Paczos-Grzęda E, Koroluk A, Okoń S, Ostrowska A, Ociepa T, Chrzasstek M, Kowalczyk K (2016) Resistance to Puccinia coronata f. sp. avenae in Avena magna, A. murphyi, and A. insularis. Plant Dis 100:1184-1191. https://doi.org/10.1094/ PDIS-06-15-0671-RE

Spearman C (1904) The proof and measurement of association between two things. Am J Psychol 15:72-101. https://doi. org/10.2307/1412159.JSTOR1412159

Tanksley SD, Young ND, Paterson AH, Bonierbale MW (1989) RFLP mapping in plant breeding: new tools for an old science. Nat Biotechnol 7:257-264. https://doi.org/10.1038/nbt0389-257

Tinker NA, Kilian A, Wight CP, Heller-Uszynska K, Wenzl P, Rines HW, Bjørnstad A, Howarth CJ, Jannink J-L, Anderson JM, Rossnagel BG, Stuthman DD, Sorrells ME, Jackson EW, Tuvesson S, Kolb FL, Olsson O, Federizzi LC, Carson ML, Ohm HW, Molnar SJ, Scoles GJ, Eckstein PE, Bonman JM, Ceplitis A, Langdon T (2009) New DArT markers for oat provide enhanced map coverage and global germplasm characterization. BMC Genom 10:1-22. https://doi.org/10.1186/1471-2164-10-39

Tomczyńska I, Śliwka J (2011) Pyramiding resistance genes in cultivated plants. Biul Inst Hod i Aklim Roślin 262:77-88

Voorrips RE (2002) MapChart: software for the graphical presentation of linkage maps and QTLs. J Hered 93:77-78. https://doi. org/10.1093/jhered/93.1.77

Wenzl P, Carling J, Kudrna D, Jaccoud D, Huttner E, Kleinhofs A, Kilian A (2004) Diversity arrays technology (DArT) for wholegenome profiling of barley. Proc Natl Acad Sci 101:9915-9920. https://doi.org/10.1073/pnas.0401076101

Werner K, Friedt W, Ordon F (2005) Strategies for pyramiding resistance genes against the barley yellow mosaic virus complex (BaMMV, BaYMV, BaYMV-2). Mol Breed 16:45-55

Wight CP, Tinker NA, Kianian SF, Sorrells ME, O'Donoughue LS, Hoffman DL, Groh S, Scoles GJ, Li CD, Webster FH, Phillips RL, Rines HW, Livingston SM, Armstrong KC, Fedak G, Molnar SJ (2003) A molecular marker map in "Kanota" $\times$ "Ogle" hexaploid oat (Avena spp.) enhanced by additional markers and a robust framework. Genome 46:28-47. https://doi.org/10.1139/g02-099

Wight CP, O'Donoughue LS, Chong J, Tinker NA, Molnar SJ (2004) Discovery, localization, and sequence characterization of molecular markers for the crown rust resistance genes $P c 38, P c 39$, and Pc48 in cultivated oat (Avena sativa L.). Mol Breed 14:349-361. https://doi.org/10.1007/s11032-005-0148-7 
Williams JG, Kubelik AR, Livak KJ, Rafalski JA, Tingey SV (1990) DNA polymorphisms amplified by arbitrary primers are useful as genetic markers. Nucleic Acids Res 18:6531-6535

Wilson WF, McMullen MS (1997) Dosage dependent genetic suppression of oat crown rust resistance gene Pc62. Crop Sci 37:16991705. https://doi.org/10.2135/cropsci1997.0011183X0037000 $60004 x$

Yan H, Martin SL, Bekele WA, Latta RG, Diederichsen A, Peng Y, Tinker NA (2016) Genome size variation in the genus Avena. Genome 59:209-220. https://doi.org/10.1139/gen-2015-0132
Ye J, Coulouris G, Zaretskaya I, Cutcutache I, Rozen S, Madden T (2012) Primer-BLAST: a tool to design target-specific primers for polymerase chain reaction. BMC Bioinform 13:134. https:// doi.org/10.1186/1471-2105-13-134

Publisher's Note Springer Nature remains neutral with regard to jurisdictional claims in published maps and institutional affiliations. 